\title{
PEDAGOGIA JANA W. GÓRY OP JAKO PRZYKŁAD PROGRAMU WYCHOWANIA ZORIENTOWANEGO NA INTEGRALNY ROZWÓJ OSOBY
}

\author{
Pedagogy of Jan W. Góra OP as an example of educational Program \\ Oriented at the Integral Development of a Person
}

Summary: The author seeks to reconstruct the pedagogy of the legendary youth priest, Dominican friar Jan Góra. To this end, she analyses his programme texts as well as his educational and pastoral activities, drawing on her own experience of collaborating with Jan Góra. The author is trying to demonstrate that Jan Góra developed a coherent educational and formative programme intended for work with youth, being a response to the contemporary societal and cultural needs. The friar developed and modified the programme based on many years' experience. The centres in Jamna and in the Lednica Fields, as well as the testimonials given by representatives of several generations of the friar's students, confirm his influence.

Keywords: Catholic ministry, priest, formation, integral personality, Lednica movement

Czas przełomu XX i XXI wieku w Polsce widziany z perspektywy pedagogicznej stanowi mozaikę różnych koncepcji i działań wychowawczych. Są one z jednej strony kontynuacją bądź adaptacją dawniejszych programów, z drugiej - próbą tworzenia nowych.

1 Prof. zw. dr hab. Katarzyna Olbrycht - kierownik Zakładu Edukacji Kulturalnej w Instytucie Nauk o Edukacji na Wydziale Etnologii i Nauk o Edukacji w Cieszynie / Uniwersytet Śląski w Katowicach. Adres: Instytut Nauk o Edukacji UŚ, ul. Bielska 52, 43-400 Cieszyn; e-mail: k.olbrycht@ onet.pl. 
Jeśli przyjąć, że istotą wychowania jest wspieranie człowieka w rozwoju i przygotowywanie go do samowychowania (także w szeroko rozumianym wymiarze duchowym - tzn. do formacji) ${ }^{2}$, należałoby założyć, że w każdym działaniu wychowawczym wybór celów, metod i form ukierunkowuje określona antropologia. Pojawia się więc pytanie, czy programy wychowania funkcjonujące $\mathrm{w}$ dzisiejszej rzeczywistości wyprowadzane są z określonych koncepcji człowieka, czy konsekwentnie do nich nawiązują, uzasadniając przyjmowane rozwiązania. Obserwacja rzeczywistości wychowawczej może budzić w tym zakresie poważne wątpliwości. Ogólnikowo formułowane cele, doraźnie preferowane wartości, nie do końca jasny, formalny podział na profilaktykę i wychowanie sprawiają, że postulat szerszego uwzględniania w instytucjach edukacyjnych działań wychowawczych rzadko przekłada się na konsekwentne programy i spójne działania.

W tym kontekście warto przyjrzeć się szczególnie tym programom, które są współczesną propozycją wychowawczego myślenia i działania opartą na wyraźnych, jednoznacznie deklarowanych założeniach antropologicznych. Nie zawsze są to dopracowane, sprawdzone systemy wychowawcze. Często ich poznanie wymaga rekonstruowania poglądów ich twórców na podstawie różnych źródeł. Także ich weryfikacja jest utrudniona ze względu na to, że realizowane w praktyce działania nierzadko są jeszcze w toku, dynamicznie się rozwijają.

Na specjalną uwagę zasługują dziś programy wspierania rozwoju integralnego, obejmującego rozwój fizyczno-psychiczny i duchowy człowieka jako osoby. Taką koncepcją jest program wychowania człowieka integralnego opracowywany i wprowadzany w życie w ostatnich latach przez dominikanina, legendarnego już dziś duszpasterza młodzieży o. Jana Wojciecha Górę OP, pisarza i poetę, twórcę letnich spotkań z młodzieżą w Hermanicach, ośrodka duszpasterskiego na Jamnej, pomysłodawcę i organizatora wydarzenia, które weszło na trwałe do polskiej kultury - spotkań młodzieży (dziś już nie tylko młodzieży, ale różnych grup) na polach lednickich, pod symboliczną Bramą-Rybą. Spotkań gromadzących co roku od kilkudziesięciu do ponad 100 tysięcy młodych ludzi. Na potrzeby spotkań na Lednicy, a przede wszystkim powołanego do życia Ruchu lednickiego i Wspólnoty lednickiej Jan Góra przedyskutowywał z młodzieżą, opracowywał i publikował materiały programowe, które pozwalają dziś merytorycznie analizować i lepiej rozumieć jego koncepcję wychowania ${ }^{3}$. Można ją także odnaleźć w licznych wywiadach, jakich udzielał zainteresowanym dziennikarzom a także autorom większych publikacji, w jego własnych tekstach, a nawet w listach

2 Takie rozumienie formacji jako przygotowania do autoformacji i samej autoformacji przyjmuję za M. Nowakiem. Por. Marian Nowak, Pedagogiczny profil nauk o wychowaniu. Studium $z$ odniesieniami do pedagogiki pielegniarstwa (Lublin: Wydawnictwo KUL 2012), 252-276.

3 Zob. teksty Jana Góry w książce stanowiące materiały programowe dla Ruchu lednickiego i Wspólnoty lednickiej: Tropy lednickie. Dzieło i program Jana Pawła II, red. Jan W. Góra OP (Poznań: Stowarzyszenie Lednica 2000, 2014). 
do Jana Pawła $\mathrm{II}^{4}$. Wizja i program wychowania powstawały w toku wieloletnich doświadczeń w pracy z młodzieżą. (Jego wychowankowie, zarówno w osobistych wypowiedziach, jak dostępnych szerzej relacjach potwierdzają ogromny wpływ Jana Góry na ich życie).

Miałam okazję przez wiele lat obserwować działania o. Jana Góry, współpracując z nim w ramach letnich kolokwiów, organizowanych początkowo dla poznańskich studentów, potem dla chętnej młodzieży w Hermanicach na Śląsku Cieszyńskim.

Jan Góra był przede wszystkim charyzmatycznym duszpasterzem młodzieży. Początkowo był rozpoznawany i popularny głównie w środowisku poznańskim, gdzie prowadził duszpasterstwo młodzieży szkół średnich, a następnie duszpasterstwo akademickie. Przyciągał młodych ludzi wyrazistą osobowością, łatwością kontaktu, niekonwencjonalnymi sposobami przybliżania do wiary i Kościoła (m.in. rezygnacją $\mathrm{z}$ hermetycznego teologicznego języka w wyjaśnianiu istoty wiary, praktyk religijnych, sensu liturgii), entuzjazmem własnej wiary, troską o piękno i powagę przeżywania sacrum. Po Światowych Dniach Młodzieży w Częstochowie w 1991 roku stał się postacią szeroko znaną i kojarzoną z duszpasterstwem młodzieży nie tylko w Poznaniu. Jego zakończona sukcesem „walka” o to, by to nie profesjonalni artyści, ale sama młodzież była najbardziej widoczna w czasie tego wydarzenia, by poczuła się za nie odpowiedzialna, pokazała wrażliwość wychowawczą Jana Góry ${ }^{5}$. Jednakże uzasadnieniem dla przedstawienia jego pedagogii jako koncepcji znaczącej dla współczesnej polskiej myśli pedagogicznej nie jest jedynie osiągnięta przez niego osobista popularność i spektakularny sukces masowych spotkań religijnych na Lednicy.

Praca każdego duszpasterza, szczególnie duszpasterza młodzieży, jest w pewnym sensie pracą pedagogiczną, intensywnym działaniem wychowawczym. Jej ważnym wymiarem jest wspieranie młodych ludzi w rozwoju duchowym, towarzyszenie im w autoformacji, która prowadziłaby do odkrywania, świadomego przeżywania i pogłębiania wiary. Wśród polskich duszpasterzy młodzieży można by wymienić wiele wybitnych osobowości, które odcisnęły silne piętno na kilku pokoleniach młodych ludzi i weszły na trwałe do historii Kościoła w Polsce. Duszpasterstwo z natury rzeczy jest znaczącym obszarem wychowania chrześcijańskiego. Wychowanie to, kształtując życie religijne wychowanków, oddziałuje

4 Por. Jan Grzegorczyk, Święty i błazen. Góra w odsłonach Grzegorczyka, wyd. II (Poznań: Wydawnictwo Polskiej Prowincji Dominikanów W drodze 2017); ...Znaczy ksiądz. Jan W. Góra OP odpowiada na pytania Joanny Kubaszczyk (Radom: Polskie Wydawnictwo Encyklopedyczne 2014); Wojciech Wiśniewski, Zapisane kartki Ojca Jana Góry. Antologia (Łomianki: Wydawnictwo LTW 2016).

5 Pomysł ten był wcześniej starannie przygotowywany w czasie letniego zgrupowania w Hermanicach, gdzie uczestnicy ćwiczyli m.in. wykonanie hymnu tego wydarzenia - pieśni Abba Ojcze, której tekst napisał w tym celu Jan Góra i który stał się jedną z najbardziej znanych pieśni religijnych w Polsce. 
równocześnie na ogólny ich rozwój. Chociaż żadna ze sfer rozwoju, a więc także rozwój religijny, nie może funkcjonować w oderwaniu od pozostałych, ich związki mogą być jednak w różnym stopniu uświadamiane i celowo włączane w program wychowania-formacji. Sposób traktowania oraz łączenia tych sfer wynika z przyjmowanej filozoficznej koncepcji człowieka i człowieczeństwa, ze sposobu rozumienia jego rozwoju.

Program wychowania chrześcijańskiego osadzony jest na teologicznej koncepcji człowieka jako obrazu Boga, dziecka Bożego, brata Chrystusa. Filozoficzną antropologią stanowiącą podstawę wychowania chrześcijańskiego jest - w świetle dokumentów Soboru Watykańskiego II - koncepcja człowieka jako osoby. Podkreśla się w niej, że rozwój osobowy musi uwzględniać wszystkie sfery ludzkiego funkcjonowania i życia, z pełnym respektowaniem godności osoby ludzkiej w życiu indywidualnym i społecznym.

Przekładanie tych założeń na praktykę wychowawczą, szczególnie w dzisiejszej rzeczywistości coraz powszechniejszego poczucia braku sensu życia, nie jest łatwe ${ }^{6}$. Wymaga głębokiego zrozumienia osobowego myślenia o człowieku, dojrzałej tożsamości chrześcijańskiej i stałego poszukiwania konkretnych rozwiązań, które pozwalałyby wcielać tę wizję człowieczeństwa w życie. Ojcu Janowi Górze udało się to niezwykle trudne zadanie. W swoim programie i działalności opierał się na antropologii filozoficznej Karola Wojtyły i chrześcijańskiej antropologii teologicznej Jana Pawła II. Uważał Jana Pawła II za swojego Mistrza, studiował jego teksty, przedstawiał mu swoje pomysły, na jego aprobacie budował motywację do działania.

Kierując się personalizmem chrześcijańskim, Jan Góra przyjął założenie orientowania pracy wychowawczej i duszpasterskiej na rozwój całego człowieka. Swoją wizję i program określał jako rozwijanie (w sobie i w innych) „człowieka integralnego". Szczególny akcent kładł na pracę nad postawami koniecznymi do życia w pełni osobowego, a równocześnie najtrudniejszymi dla młodzieży, najbardziej zaniedbanymi w obecnej praktyce wychowawczej i marginalizowanymi przez współczesną kulturę. Za takie postawy uważał dojrzałość, samodzielność i odpowiedzialność.

Dochodzenie do tego programu wiązało się z drogą życiową o. Jana Wojciecha Góry OP.

6 Por. na ten temat Teresa Zawojska, „Wychowanie oparte na wartościach chrześcijańskich jako odpowiedź na poczucie kryzysu sensu we współczesnym świecie”, Paedagogia Christiana 2/40 (2017): 33-51. 


\section{Życiowa i pedagogiczna droga o. Jana Wojciecha Góry OP}

Jan Wojciech Góra urodził się w 1948 roku w Prudniku na Opolszczyźnie, gdzie ukończył Liceum Ogólnokształcące i szkołę muzyczną I stopnia (w klasie klarnetu). Po maturze wstępuje do Zakonu Braci Kaznodziejów (dominikanów) w Poznaniu. W 1967 roku rozpoczyna studia filozoficzne w Kolegium Filozoficzno-Teologicznym Ojców Dominikanów w Krakowie. Po otrzymaniu święceń kapłańskich w 1974 roku zostaje skierowany do klasztoru w Tarnobrzegu, gdzie prowadzi lekcje religii w klasach VI i VII. Pozostaje tam jedynie przez rok, aby następnie przenieść się do klasztoru warszawskiego, obronić pracę magisterską i rozpocząć studia doktoranckie w Akademii Teologii Katolickiej (zakończone obroną doktoratu $\mathrm{z}$ teologii w roku 1981). W roku 1977 zostaje skierowany do Poznania, gdzie obejmuje duszpasterstwo młodzieży szkół średnich. Będzie je prowadził do roku 1987. Od roku 1984 do tych obowiązków dojdzie opieka nad poznańskim duszpasterstwem akademickim. Stanie się ona zadaniem, któremu Jan Góra poświęci całe swoje życie. W nowej sytuacji pojawiają się nowe inicjatywy i działania. W 1988 roku rozpoczynają się coroczne letnie „Kolokwia” w Hermanicach, obejmujące trzytygodniowe sesje zatytułowane: Wiara, Nadzieja, Miłość. W 1992 roku o. Jan Góra przejmuje otrzymaną od gminy Zakliczyn starą szkołę z dużym terenem na górze Jamna, z przeznaczeniem na ośrodek duszpasterstwa akademickiego. Wreszcie w 1995 roku wobec możliwości pozyskania pól nad Jeziorem Lednickim rodzi się pomysł stworzenia tam ośrodka duszpasterskiego już nie tylko dla poznańskich studentów, ale dla całej polskiej młodzieży. Najważniejszym symbolicznym elementem tego miejsca miała być Brama Trzeciego Tysiąclecia w kształcie ryby (symbolu pierwszych chrześcijan). Najważniejszym momentem - przejście przez Bramę-Rybę, jako znak osobistego wyboru Chrystusa. Dwa lata później, w 1997 roku ma miejsce pierwsze spotkanie młodych na Lednicy. Lednica stała się, jak stwierdził Jan Góra, najważniejszym zadaniem wychowawczym i duszpasterskim. Dla jego realizacji w 2011 roku powołuje do życia Ruch lednicki i Stowarzyszenie Lednica 2000, a w 2012 roku Wspólnotę lednicką, skupiającą ludzi identyfikujących się z duchową wizją Lednicy i gotowych pomagać $w$ jej realizacji. Opracowuje dla tych środowisk materiały programowe i formacyjne. W roku 2014 ukazuje się książka Tropy lednickie. Dzieło i program Jana Pawła II stanowiąca zbiór materiałów przeznaczonych do pracy z młodzieżą według „programu lednickiego". W książce tej Jan Góra, obok tekstów zaproszonych Autorów, którzy także w przesłaniach Jana Pawła II do uczestników spotkań na Lednicy odczytali wyraźny program autoformacji, zawarł własny program wychowawczy i formacyjny.

Ważnym nurtem aktywności Jana Góry, niezależnie od działalności duszpasterskiej wśród młodzieży, była twórczość pisarska. Obejmowała współpracę

Tropy lednickie. 
z czasopismami katolickimi - „Przewodnikiem Katolickim”, „Tygodnikiem Powszechnym”, miesięcznikiem „W drodze”, a także bogatą twórczość literacką - opowiadania i książki (ponad 30), odwołujące się najczęściej do własnych doświadczeń, przeżyć, spotkań. Wśród wielu nagród i wyróżnień warto w tym kontekście wspomnieć o otrzymanej przez niego w 1983 roku Nagrodzie Literackiej Fundacji im. Kościelskich w Genewie, za książkę Mój świat. Aktywność pisarska nie była w życiu Jana Góry sferą odizolowaną od działania duszpasterskiego i wychowawczego. Była szczególnym dopełnieniem, czasami - bez cienia dydaktyzmu czy moralizatorstwa - refleksją nad tym działaniem. Pisane piękną polszczyzną, niejednokrotnie bardzo osobiste teksty wzmacniały bezpośrednie oddziaływanie, równocześnie pozwalały lepiej poznać Autora, przede wszystkim jego głęboką wiarę wyznaczającą stosunek do świata, do ludzi, w tym - do wychowanków, motywacje życiowych decyzji, źródła porywających wizji.

W roku 2012 o. Jan Góra przestał być duszpasterzem akademickim i został przez swój zakon powołany na funkcję głównego duszpasterza Jamnej i Lednicy. Do końca dzieląc swoje życie między Wspólnotę lednicką, ośrodki na Lednicy i na Jamnej, spotkania w Hermanicach, Jan Góra zmarł w grudniu 2015 roku w Poznaniu, odprawiając mszę świętą roratnią dla Wspólnoty lednickiej.

Wśród wielu odznaczeń, nadanych mu tytułów i nagród, szczególnie dwa potwierdzają jego pedagogiczne zasługi, podkreślone w oficjalnym uzasadnieniu. Są to przyznany w 2011 roku przez Prezydenta RP Krzyż Komandorski Orderu Odrodzenia Polski „za wybitne osiągnięcia w kształtowaniu postaw patriotycznych i moralnych młodzieży oraz dokonania w pracy duszpasterskiej” i Honorowe Obywatelstwo Miasta Poznania przyznane w 2007 roku przez Radę Miasta Poznania jako „wyraz wdzięczności za 30 lat pracy duszpasterskiej i wychowawczej z poznańską młodzieżą i studentami [...]"”.

\section{Jan W. Góra OP duszpasterz i wychowawca}

Zanim Jan Góra sformułował swój program wychowawczy, w codziennej pracy z młodzieżą programowo przyjął postawę ojca, której sens i znaczenie odnalazł w dramacie Karola Wojtyły Promieniowanie ojcostwa. Człowiek, tak rodzic, jak dziecko, jest w nim ukazany w całej swojej osobowej złożoności, we wszystkich wymiarach i sferach człowieczeństwa (zgodnie $\mathrm{z}$ antropologią personalistyczną Wojtyły). Postawa wychowawcza Jana Góry była świadomie kształtowaną postawą ojca - bezinteresownie kochającego, wskazującego drogę rozwoju, motywującego i stwarzającego warunki do samodzielnego podążania tą drogą, wymagającego, ale zawsze gotowego do pomocy, ufającego w odpowiedzialność dziecka, ale pozostawiającego mu wolność decyzji.

\footnotetext{
8 Wiśniewski, Zapisane kartki, 422-433.
} 
Sposób myślenia o człowieku kształtujący się pod wpływem filozofii Wojtyły i nauczania Jana Pawła II stanie się stopniowo podstawą wizji „człowieka integralnego", którą Jan Góra przyjmie za główny kierunek swoich działań duszpasterskich i wychowawczych. Będzie w nich podkreślał potrzebę dorastania do dojrzałości, samodzielności i odpowiedzialności ludzkiej i chrześcijańskiej. Będzie dbał o niezbędną $\mathrm{w}$ tym procesie formację intelektualną, moralną i kulturalną swoich wychowanków, o rozwój całego człowieka. Sam miłośnik i znawca kultury, szczególnie kultury polskiej, zaprzyjaźniony z wieloma ludźmi nauki i kultury, starał się w kontakty z nimi wprowadzać swoich wychowanków. Chciał ich nauczyć rozumienia wartości kultury, jej miejsca w rozwoju człowieka, narodu, społeczeństw i ludzkości. Kulturę uznawał za sferę duchowego wzrastania, a jej wytwory - za cenne świadectwa tego trudnego procesu. Obdarzony artystyczną wrażliwością zwracał uwagę na piękno w przyrodzie, w dziełach kultury, szczególnie w literaturze, muzyce, w języku. Daleki od sztucznego formalizmu, przywiązywał dużą wagę do formy w świecie i w życiu, wymagał staranności w jej celowym konstruowaniu odpowiednio do potrzeb i znaczenia podejmowanych działań.

Gdyby mówić o służącej temu celowi metodzie wychowawczej, można uznać, że niezależnie od wspólnego spędzania czasu (spotkania, rozmowy, czytanie ważnych tekstów - np. Jana Pawła II, ale i Mickiewicza Pana Tadeusza, wyjazdy, obozy itp.) obejmowała ona powierzanie młodym ludziom konkretnych zadań - od drobnych do coraz trudniejszych, wymagających samodzielności i odpowiedzialności. Zakładała rozwijanie świadomości, że jeśli jest się w jakiejś wspólnocie, tworzy się ją, jest się darzonym zaufaniem innych, trzeba poświęcić czas, zdolności, siły dla realizacji wspólnego dobra. Warto przypomnieć jedno $\mathrm{z}$ charakterystycznych, znaczących wychowawczo zachowań o. Jana. Często kiedy był zapraszany, bardziej czy mniej oficjalnie, zabierał ze sobą kogoś ze „swoich dzieci” z duszpasterstwa, chcąc podkreślić wagę budowanych w tej wspólnocie więzi, wspólnego zaangażowania i współodpowiedzialności.

Wszystkie te zachowania i działania dotyczyły zarówno formacji religijnej np. udziału w przygotowywaniu pięknej liturgii (Jan Góra zapoczątkował w duszpasterstwie młodzieżowym m.in. zwyczaj wspólnej modlitwy brewiarzowej i specjalnie celebrowanych porannych rorat), jak i tworzenia różnego rodzaju sytuacji wychowawczych. Każdy z młodych ludzi czuł się dostrzeżony, ważny, akceptowany i oczekiwany. Każdy mógł liczyć na czas i gotowość pomocy o. Góry, mógł być pewien, że ten przywita go z radością. Gdy ktoś decydował się na bardziej systematyczny kontakt, stopniowo stawał się jego wychowankiem i współpracownikiem, czuł się potrzebny, kochany, zobowiązany do pracy nad sobą choćby ze względu na oczekiwanie ojca, jego wiarę, że podjęty wysiłek nie będzie daremny.

Jan Góra nie tylko realizował określoną koncepcję pracy z młodymi ludźmi. Był sam wiarygodnym przykładem życia ideałami, które przekazywał. Żył 
radykalną, nieskrywaną miłością do Chrystusa i do swoich wychowanków, nie pozostawiając „dla siebie” ani czasu, ani sił. Ten jednoznaczny, wyrazisty model życia przyciągał i fascynował młodzież.

Jednym z pierwszych bardziej odpowiedzialnych, tworzących ważną sytuację wychowawczą zadań, w które została zaangażowana młodzież z poznańskiego duszpasterstwa, była organizacja letnich kolokwiów w Hermanicach.

Formuła tych spotkań zapowiadała już kierunek i metody działań wychowawczych Jana Góry. Można by ją streścić krótko: uczestnicy - poznańscy studenci - mieszkający w namiotach na hermanickiej łące, zajęcia odbywające się początkowo $\mathrm{w}$ dużym namiocie, potem na powietrzu pod wiatą. Plan dnia obejmujący wspólną modlitwę brewiarzową, śpiewy, posiłki przygotowywane w kuchni polowej, wykłady, spotkania i dyskusje z zaproszonymi przez Jana Górę gośćmi - ludźmi kultury, nauki, teologami, wycieczki beskidzkimi szlakami, wieczorne spotkania, koncerty i tańce przy ognisku. Niezależnie od atrakcyjności tego programu znamienna wychowawczo była konsekwentna postawa o. Jana, sprawdzona w całorocznej pracy duszpasterskiej z młodzieżą. Przydzieleni do poszczególnych organizacyjnych „sektorów” młodzi ludzie musieli się wykazać dużą samodzielnością, ale i odpowiedzialnością za powierzone im zadanie. Choć obdarzeni pełnym zaufaniem, nigdy nie byli jednak pozostawiani sami sobie. Ojciec Góra nie „wyręczał się” nimi, ale był „wszędzie”, 24 godziny na dobę z ludźmi, zawsze do dyspozycji w razie wątpliwości czy problemów. Konsekwentnie realizował postawę ojcowską i osobową. Starał się poznać wszystkich uczestników po imieniu, coś o nich wiedzieć, zamienić przynajmniej kilka zdań, każdego wyjeżdżającego pożegnać z osobna, co nie było łatwe przy przewijających się przez te spotkania kilkuset uczestnikach. Także wybór tematyki kolokwiów wynikał z określonych założeń - orientacji na wartości. Miał uruchamiać w młodym człowieku potrzebę wewnętrznej formacji, szukania Boga, wejścia na drogę wiary, pracy nad sobą poprzez intensywne zaangażowanie religijne (wspólną modlitwę brewiarzową, śpiewy, msze święte) ale też zaangażowanie intelektualne (wykłady i dyskusje na tematy z pogranicza religii i nauki, religii i kultury), wreszcie organizację życia wspólnotowego (dyżury, służby) i atrakcyjnie wspólnie spędzany czas (poznawanie regionu, warsztaty taneczne, koncerty). Wszystko to składało się na specyficzną kulturę hermanickich spotkań, bowiem kulturę Jan Góra uważał za sferę duchowego wzrastania człowieka, a w powstających na tej drodze dziełach i ważnych dla człowieka symbolach widział szczególnie cenne elementy świata.

Kolejnym etapem i wyzwaniem wychowawczym okazała się budowa, zagospodarowywanie fizyczne i „treściowe” ośrodka na Jamnej. Położona na szczycie góry stara szkoła i otaczający ją teren, naznaczony tragiczną historią pacyfikacji miejscowej wsi przez Niemców w czasie II wojny światowej, miały być w planach o. Jana Góry prawdziwym wspólnym domem społeczności duszpasterstwa akademickiego i jego przyjaciół. 
Była przestrzenią pozwalającą przez cały rok, poprzez fizyczną i duchową pracę wokół własnego domu realizować ideę wychowywania młodych ludzi do dojrzałości, rozwijania $\mathrm{w}$ nich odpowiedzialności i samodzielności $\mathrm{w}$ budowaniu dobra wspólnego. Czas spędzany w przepięknym górskim otoczeniu jamneńskiego domu oznaczał nie tylko radość kontaktu z naturą, atrakcje turystyczne, spotkania z przyjaciółmi, ale zwyczajne codzienne obowiązki i fizyczne prace przy domu. Była też Jamna przestrzenią wychowawczo zobowiązującą, bo nasyconą dramatyczną treścią historyczną. Ojciec Jan $\mathrm{z}$ aktywnym udziałem zapraszanej młodzieży i przyjaciół rozbudowywał to miejsce i tworzył jego kulturę, organizując ciekawe wydarzenia, spotkania, wykłady i dyskusje, wprowadzając nowe tradycje (m.in. specjalnie uroczyste obchodzenie 15 sierpnia święta Matki Bożej Zielnej, wspólna pasterka i sylwester, wydarzenia kulturalne - np. doprowadzenie do wystawienia na jamneńskim szczycie Harnasiów Szymanowskiego), zwożąc ważne pamiątki, wreszcie budując kościól. Dziś Jamna to prawie mała wioska kilka usytuowanych na szczycie góry niewielkich budynków, kościół, pustelnia, miejsce na spotkania pod wiatą. Kultura Jamnej miała pomagać ludziom w trudnym zadaniu wzrastania i dojrzewania w wierze w warunkach codziennej wspólnej pracy, odkrywania wartości, uważnego słuchania i rozmawiania. Równocześnie o. Góra szukał sposobów, które w naturalny sposób uczyłyby młodych ludzi wyzwalania się z egocentryzmu, jaki w sytuacji życia grupowego stawał się szczególnie widoczny. To nastawienie o. Jana dobrze ilustruje pomysł sprowadzenia na Jamną osła (później także na Lednicę), „,wyżebranego” w poznańskim ogrodzie zoologicznym i uroczyście włączonego (jako doctora humoriscausa) w społeczność duszpasterstwa akademickiego. W jednym z wywiadów Jan Góra opowiada:

Osioł pochłaniał wiele energii, ale tworzył atmosferę, był nośnikiem żartu, idei oraz elementem pedagogicznym duszpasterskiego ośrodka. [...] Kiedy siadaliśmy do śniadania, pytałem najpierw, czy osioł dostał jedzenie, wtedy studenci podrywali się i biegli do stajenki. Te zabiegi spowodowały, że ci ludzie zaczynali się uczyć myśleć o kimś innym poza sobą samym?

Poszukując programu wychowawczego, o. Jan Góra odwoływał się do największego swojego autorytetu i Mistrza - Jana Pawła II. Kierunek własnej formacji odnalazł w Promieniowaniu ojcostwa Wojtyły. Dla wychowanków, z którymi często czytał teksty Jana Pawła II, wybrał jako główne przesłanie jedno z podstawowych założeń personalizmu K. Wojtyły - Jana Pawła II (występujące także w dokumentach Soboru Watykańskiego II): „Człowiek nie może odnaleźć się $\mathrm{w}$ pełni inaczej, jak tylko poprzez bezinteresowny dar $\mathrm{z}$ siebie samego" ${ }^{10}$. Stwierdzenie to o. Góra często analizował z młodzieżą. Wymagał, by jego wychowankowie znali je na pamięć i potrafili w każdej chwili zacytować. Uważał, że głęboko

9 Grzegorczyk, Święty i błazen, 130.

${ }_{10}$ Konstytucja duszpasterska Soboru Watykańskiego II (KDK 24). 
przyswojone może wyznaczać życiowy kierunek, szczególnie w epoce rosnącego egocentryzmu i promowanego egoizmu.

\section{Miejsce Lednicy w pedagogii Jana Góry}

Ostateczne sformułowanie przez o. Jana Górę programu wychowawczego jest związane z powstaniem i konkretyzacją jego wizji Lednicy, jako miejsca corocznych religijnych spotkań polskiej (z czasem przybywającej z całej Europy i świata) młodzieży. Pola nad Jeziorem Lednickim - historyczne miejsce chrztu Polski i zwoływane tam w czerwcu spotkania młodzieży miały budzić potrzebę budowania własnej tożsamości opartej na wartościach chrześcijańskich, duchowych i patriotycznych. Centralnym elementem scenariusza tych spotkan był symboliczny akt osobistego wyboru Chrystusa, dokonywany poprzez przejście przez bramę w kształcie ryby - znaku pierwszych chrześcijan. Jednak równie ważne okazało się wysłuchanie przesłania Ojca Świętego (przez osiem lat przekazywane przez Jana Pawła II, potem przez Benedykta XVI i dziś - przez papieża Franciszka). Ojciec Góra tak wyjaśniał ideę Lednicy: „Pojawiła się wizja zjednoczenia młodzieży wokół Chrystusa wybieranego coraz bardziej świadomie nad brzegami Jeziora Lednickiego, czyli u źródeł chrzcielnych Polski. Tysiące młodych przybywających na Lednicę przybywa tam po sens, po ewangeliczną treść [...]"11. Lednica w wizji Jana Góry miała być historycznym i symbolicznym miejscem świadomego wyboru wiary, stwarzającym niejako naturalną szansę przywrócenia kolejnym pokoleniom chrześcijańskiego celu i sensu życia, motywacji do budowania w sobie człowieczeństwa „integralnego”. Równocześnie tak poważne zadanie miało pozwolić ludziom młodym w jakimś stopniu już uformowanym, mającym pewne doświadczenie w pogłębianiu swojej wiary, rozumiejącym sens wspólnoty, odnaleźć sens i cel działania na miarę ich możliwości i potrzeb czasu. Lednica, będąc miejscem formacji dla ludzi znajdujących się na różnych etapach drogi do wiary, miała też uczyć pomagania na tej drodze innym. Spotkania miały być stworzeniem sytuacji umożliwiającej młodym ludziom, niezależnie od poziomu ich wiary i religijnego zaangażowania, uświadomienie sobie znaczenia i przeżycie wartości wiary, wartości patriotycznych, wartości osobowych i wspólnotowych.

W świetle nauczania Jana Pawła II, jeśli Lednica miała być miejscem przybliżającym młodych ludzi do wiary, powinna stwarzać warunki doświadczania kultury niosącej wyrazisty przekaz wiary, a równocześnie wyrażania wiary w nowych formach, odpowiadających potrzebom młodzieży. Powinna przekładać wiarę na kulturę, a więc wypracowywać własną kulturę, która nadałaby przeżywaniu treści religijnych formę bliską młodym ludziom, niosącą czytelne dla nich znaczenia. Dziś, po dwudziestu latach lednickich doświadczeń kultura lednicka

11 Wiśniewski, Zapisane kartki, 398. 
zakorzeniła się już w kulturze polskiej. Rozpoznawalny jest jej symbol - ogromna stalowa Brama-Ryba, znane są pieśni i tańce lednickie rozpropagowywane w całym kraju przez grupę muzyków - zespół Siewcy Lednicy - współpracujących z Janem Górą. Wyrazem intuicji wychowawczej i znajomości współczesnej młodzieży były scenariusze lednickich spotkań. Wspólna modlitwa, piękna liturgia i uroczysty akt przejścia przez Bramę-Rybę jako symbol wyboru Chrystusa były obudowane bogactwem obrazów, obrzędów, wrażeń odwołujących się do różnych zmysłów, wspólnym śpiewem, tańcem, szybko zmieniającą się akcją. Każdy z uczestników otrzymywał dar-symbol, związany z tematem danego spotkania. Były to niewielkie przedmioty (m.in. woreczek z solą, pierścień, drewniane wiosełko, słoiczek miodu, moneta - lednicki talent, krzyżyk, klucz, metalowa rybka), ważne teksty (małe brewiarze, wypisy z Dzienniczka św. Faustyny). Uczyły one sensu bezinteresownego daru. Zabierane ze sobą pozwalały żyć pamięcią o zakończonym spotkaniu, o jego przesłaniu, wzmacniały jego wychowawczy przekaz. Niektóre przybliżały doświadczenie prawdziwej relacji i wspólnoty, kiedy miały być ofiarowane komuś drugiemu (jak rybka - dla przyjaciela). Z czasem zaproszenie na Lednicę zaczęło się łączyć ze szczególną wymianą darów - przywiezieniem wskazanych rzeczy-symboli łączących się z tematyką danego spotkania (kamienia, przepisanego fragmentu Biblii, kluczy). Ojciec Góra, tłumacząc wprowadzanie na Lednicy wciąż nowych symboli, mówił:

Kapłan czy każdy człowiek pracujący z młodzieżą z jednej strony musi się w nią wsłuchiwać, ale też wydobywać z niej to, co uśpione, zakopane. Na dzisiejszym wolnym rynku króluje materialna tandeta i zwodnicze idee, swoje stragany porozstawiały sekty. Chrześcijańskie symbole religijne jawią się jak latarnie morskie, drogowskazy, które są nam niezbędne, żeby się uporać z tą magmą. [...] Musimy konkurować - choć to złe słowo - raczej być alternatywą wobec propozycji ciągnących młodych ludzi $\mathrm{w}$ dół ${ }^{12}$.

Idea spotkań na polach lednickich, pod Bramą-Rybą, która wyrosła z głęboko przemyślanej wychowawczej wizji o. Jana Góry, spotkała się z aprobatą Jana Pawła II. Jej wyrazem i potwierdzeniem stały się przekazywane corocznie (od 1997 do 2005 roku) przesłania połączone z błogosławieństwem. Otrzymane od Jana Pawła II w czasie kolejnych ośmiu spotkań lednickich przesłania utworzyły zarys spójnego programu formacji, prowadzącego do świadomego odkrycia i wyboru Chrystusa, podążania za Nim, odpowiedzialnego włączenia się we wspólnotę Kościoła ${ }^{13}$. Program ten Jan Góra analizował i dopracowywał do końca życia.

12 Grzegorczyk, Święty i błazen, 217-218.

13 Treść wszystkich przesłań i komentarze do nich zawierają m.in. publikacje: $8 \times \mathrm{JP} I \mathrm{I}$, red. Jan W. Góra (Poznań: Duszpasterstwo Akademickie Dominikanów 2009); Tropy lednickie; Podręcznik Pokolenia JPII. Ojcowskie słowo do młodych świata, Polski i Lednicy, red. Jan W. Góra (Poznań: Lednica 2000 Duszpasterstwo Akademickie Dominikanów 2008). 


\section{Wychowanie „człowieka integralnego”}

W materiałach programowych dla Ruchu lednickiego Jan Góra napisał: „Uświadomiona tożsamość lednicka to wybór Chrystusa i rozwój integralnej osobowości [podkr. K.O.]. To wyzwolenie potencjalności, którą Bóg złożył w każdym z nas. Dojrzałość, samodzielność, odpowiedzialność osobowa winny znamionować ludzi Lednicy" ${ }^{14}$.

W tym ostatnim sformułowaniu widać już wyraźnie wychowawcze założenie lednickiej idei. Z wyborem Chrystusa wiąże się ściśle rozwój o s ob owości integralnej, budowanie w sobie człowieka integralnego. Człowieczeństwo integralne pozwala coraz bardziej świadomie i konkretnie, w codziennym życiu iść za Chrystusem, i na tej drodze stawać się osobowym darem dla innych.

Wizja „człowieka integralnego” nie została przez Jana Górę jednoznacznie wyjaśniona, jednakże analiza jego wypowiedzi i tekstów pozwala dotrzeć do znaczenia, jakie wiązał z tym określeniem. W Tropach lednickich możemy przeczytać:

Średniowieczni myśliciele stworzyli pojęcie prawdy moralnej, polegającej na zgodności myśli, słowa i czynu. To stwarza osobowość integralną, a dzisiejszym językiem autentyczną. Dojrzeć do tego, by mieć stosunek do samego siebie i sobą odpowiedzialnie dysponować, dojrzeć do świadectwa przed sobą samym, przed wspólnotą i wiecznością. W istocie chodzi o doskonałą, a nawet heroiczną miłość Boga i bliźniego. Dojść do spełnienia siebie samego, swojej misji i swojego powołania ${ }^{15}$.

W zacytowanym fragmencie i wielu innych miejscach czytelne jest sięganie przez o. Górę do antropologii Wojtyły i Jana Pawła II. Można tam odnaleźć dwa wymiary „integralności” człowieka, które ściśle się ze sobą łączą. Jeden - to bycie osobą wewnętrznie zintegrowaną (człowiekiem dojrzałym, samodzielnym, odpowiedzialnym, istotą obdarzoną godnością ludzką). Drugi - to integralność łącząca dojrzałe, odpowiedzialne (osobowe) człowieczeństwo z dojrzałym, odpowiedzialnym chrześcijaństwem.

W pierwszym rozumieniu $\mathrm{w}$ człowieku jako osobie integralnie łączą się wymiar fizyczno-cielesny, psychiczny i duchowy. Jednak ostatecznie to wymiar duchowy nadaje kierunek osobowemu rozwojowi człowieka. Integrowanie w sobie mechanizmów i procesów psychofizycznych umożliwia samostanowienie, warunkuje to, że człowiek rozwija się, dążąc w sposób rozumny i wolny, a w konsekwencji odpowiedzialny do prawdy, do realizacji dobra moralnego, do odkrywania i kontemplacji piękna, w ten sposób spełniając siebie. Obdarzony bezwarunkową godnością człowiek jest najwyższą w świecie wartością. Na tej podstawie przysługuje mu szacunek i miłość, rozumiana jako bezinteresowny dar z siebie. Jedynie będąc darem dla drugiego i innych, może on w pełni uczestniczyć

\footnotetext{
14 Tropy lednickie, 16.

15 Tamże, 106.
} 
we wspólnotach, w których przyszło mu żyć. Uczestnictwo to wymaga, by solidarnie troszczyć się o rozwój osobowy innych członków wspólnoty, sprzeciwiać się sytuacjom zagrożenia ich godności i warunków rozwoju, bronić wspólnych wartości, a w sytuacjach trudnych nie zajmować postaw konformizmu i uniku, ale solidarności. Tylko tak pojmowane uczestnictwo pozwala spełnić siebie, zrealizować swój potencjał, a w świetle wiary - w pełni zaangażować i wykorzystać dane przez Boga talenty, świadomie podejmując i realizując swoje powołanie. Trzeba więc naturalny w człowieku egocentryzm stopniowo zastępować dostrzeganiem potrzeb innych, rozwijaniem allocentryzmu (za Janem Górą - „alterocentryzmu”), przyjmowaniem odpowiedzialności za wspólne dobro. „Człowiek integralny" byłby to więc człowiek starający się tak uformować swoją osobowość, by zawsze kierować się prawdą, rozstrzygać w jej świetle na rzecz dobra moralnego. Równocześnie byłby to człowiek łączący tak rozumianą dojrzałość osobowościową z dojrzałością chrześcijańską, dojrzałością wiary. Wymaga ona, by wszystkie zachowania i działania, myśli i uczucia wytrwale orientować na główny cel - osiągnięcie świętości i zbawienia. Drogą do tego celu jest miłość Boga i ludzi, droga, na której przewodnikiem jest Chrystus.

We wspomnianej publikacji Tropy lednickie. Dzieło i program Jana Pawła II Jan Góra przedstawił propozycję programu wychowawczego i formacyjnego, który opracował na potrzeby środowisk powstałych wokół spotkań lednickich: Ruchu lednickiego i Wspólnoty Lednica 2000. Program zatytułował: „Wizja rozwoju osobowości integralnej”. Program ten miał być niejako przełożeniem ośmiu papieskich formacyjnych zadań-wezwań, stanowiących kolejne „kroki” dojrzewania i wzrastania w wierze, na zadania ukierunkowujące pracę nad sobą oraz pomoc innym wchodzącym na tę drogę. Dlatego program ten o. Góra uważał za dzieło w głównej mierze Jana Pawła II. Cel wyznaczający treść programu został przez o. Górę sformułowany następująco: „wychować i przygotować zintegrowaną osobowość otwartą młodego człowieka do pełni uczestnictwa w życiu społecznym, w życiu Kościoła oraz w życiu wiecznym"16. Opracowany w syntetycznej formie program pracy nad budowaniem w sobie „człowieka integralnego" i wychowawczym wspieraniem tej pracy u innych, dzieli się - odpowiednio do poszczególnych papieskich przesłan - na trzy etapy, stanowiące niejako stopnie zaawansowania. Jan Góra nazwał je „kursami”, pokazując tym samym, że pracę nad osiąganiem dojrzałości traktuje jako poważną, systematyczną pracę samowychowawczą nad własną dojrzałością. Program obejmuje: „Kurs podstawowy”, „Kurs zaawansowany” oraz jako najwyższy, uzupełniający „Kurs dojrzałości ludzkiej i chrześcijańskiej” ${ }^{17}$. Kurs podstawowy miał być skoncentrowany na uczeniu się budowania relacji i więzi, na odpowiedzialności za siebie i innych,

16 Tamże, 56.

17 Każdy z kursów odwołuje się do konkretnych przesłań papieskich: kurs podstawowy - do przesłań 1.,2., i 3., kurs zaawansowany - do przesłań 4., 5., i 6., ostatni - do przesłań 7. i 8. 
ale też za wiarę, Boga, Kościół i Ojczyznę. Kurs zaawansowany miał uświadamiać sens daru miłości Chrystusa, miejsce i znaczenie słowa Bożego w życiu, potrzebę świadomego uczestnictwa we wspólnocie. Ostatni z wyodrębnionych kursów to budowanie „dojrzałości społecznej” i przygotowanie do świadomego „spełnienia” swojego życia, swojego powołania - oparte na łączeniu wiary z życiem, na wierze przekładanej na kulturę, na bezinteresownej służbie innym (myśleniu o wspólnocie w kategoriach: „my dla innych”), na tworzeniu środowiska zdolnego i gotowego pomagać innym w odkrywaniu powołania do świętości i w dążeniu do niej. Ostatni kurs miał pomóc zobaczyć szczęście w osobowym i chrześcijańskim spełnieniu własnego życia. Ideowym przewodnikiem i patronem każdego z kursów został inny święty, odpowiednio do tematyki i zadań (kolejno św. Wojciech, św. Stanisław, św. Jacek, św. Jan Paweł II, św. Paweł Apostoł, Matka Boża, św. Dominik i św. Piotr). Projekt ten został sformułowany przez o. Jana Górę z myślą o uczestnikach znajdujących się na różnych etapach formacji i doświadczenia lednickiego, a więc z jednej strony o „przeciętnych” uczestnikach spotkań lednickich, z drugiej - o współpracownikach organizujących te spotkania. Zakładał, że uczestnictwo w spotkaniach lednickich, pogłębiane całoroczną pracą nad kolejnymi krokami programu formacyjnego, będzie motywowało do systematycznej formacji, a także do coraz bardziej świadomego i odpowiedzialnego uczestnictwa w Ruchu lednickim. We Wstępie do Tropów lednickich możemy przeczytać: „Grupa ludzi (młodzieży i starszych) gromadząca się wokół tych dzieł, usiłująca żyć programem, który pozostawił nam święty Papież, z biegiem lat uzyskała swoją tożsamość i odrębność, świadomość misji i zadań. Podejmuje samokształcenie oraz kształci innych"18.

W programie rozwoju osobowości integralnej Jan Góra wskazał, jakie zadania w zakresie rozwoju osobowego (w tym - harmonijnego rozwoju osobowościowego) trzeba podjąć, jaką wiedzę uzyskać, jakie umiejętności i postawy wykształcić, by możliwa była pełna realizacja papieskich wezwań formacyjnych. W oparciu o antropologię filozoficzną Wojtyły podkreślał konieczność wychowawczego prowadzenia człowieka (i pracy nad sobą) od uczenia (się) relacji pełnych szacunku i miłości, przez świadome budowanie wspólnot i osobowe w nich uczestnictwo, do otwierania się na społeczeństwo, wnoszenie pozytywnego wkładu w jego rozwój, wreszcie do świadomego podejmowania zadań związanych $\mathrm{z}$ odpowiedzialnością za życie Kościoła. Podsumowując programy dwóch pierwszych kursów wspierających rozwój osobowości integralnej, Jan Góra pisał:

Po ukończeniu cyklu kształcenia i wychowania można oczekiwać od jego uczestnika pewnej wiedzy, pewnej samodzielności i dojrzałości. Każdy odkrywa w sobie nie dające się stłumić wezwanie, które jednocześnie określa jego godność i odpowiedzialność. „Stań się" tym, czym „jesteś”. Osobą, osobowością, integralną osobowością,

18 Tropy lednickie, 16. 
osobowością otwartą na transcendencję Boga człowieka. Można wskazać cztery tory rozwoju osoby. Pierwszy to doskonalenie w miłości, drugi - służba życiu, trzeci uczestnictwo w rozwoju społeczeństwa, czwarte - uczestnictwo w życiu i posłannictwie Kościoła ${ }^{19}$

Program wychowania „człowieka integralnego” został przez Jana Górę opracowany na potrzeby pracy formacyjnej realizującej ideową wizję Lednicy. Stanowił jednak efekt wcześniejszych wieloletnich doświadczeń w pracy z młodzieżą i nieustannego uczenia się od Mistrza - Jana Pawła II, który pokazał - głównie $\mathrm{w}$ przemówieniach do młodzieży, ale też w lednickich przesłaniach - kierunek pracy nad dojrzewaniem w wierze, podpowiadając kolejne kroki na tej drodze. Nie przypadkiem Jan Góra doprowadził do bardzo starannego wydania publikacji zawierającej przemówienia Jana Pawła II do młodzieży Podręcznik Pokolenia $J P I I^{20}$, Ojciec Jan Góra, idąc za swoim Mistrzem, koncentrował się na przekazie wiary w Chrystusa, na tworzeniu warunków do osobistego spotkania z Chrystusem, pamiętając jednak o roli, jaką w tym procesie odgrywa harmonijny rozwój ludzki, o potrzebie odwoływania się w wychowaniu do antropologii uznającej w człowieku osobę. Dlatego tak konsekwentnie budował swoją wizję wychowania na fundamencie antropologii filozoficznej i teologicznej, na personalizmie Wojtyły - Jana Pawła II. Próbę tę można uznać za ważny wkład we współczesną polską myśl pedagogiczną. Nie tylko wizja i program zasługują na uważną analizę. Pedagogię o. Jana Góry dopełniają jego działania i postawy zgodne z przyjętą wizją dążenia do osobowości integralnej. Troska o to, żeby każdy napotkany człowiek czuł się jako osoba szanowany i kochany, ale też żeby stale pracować nad własnymi błędami i niekonsekwencjami weryfikowały Jego wiarygodność wychowawczą.

Niezależnie od dalszych losów rozpoczętych i planowanych przez Jana Górę przedsięwzięć, ilość ludzi z kilku już pokoleń objętych wychowawczym i formacyjnym oddziaływaniem Jana Góry skłania do uważnej analizy jego pedagogii, wychowawczych wizji tworzonych $\mathrm{z}$ rozmachem i odwagą, realizowanych $\mathrm{z}$ nieustępliwą determinacją.

Warto zacytować fragment jednej z jego wypowiedzi:

Po latach pracy z młodzieżą przekonałem się, jak ważną rolę w kształtowaniu dojrzałej osobowości odgrywa wizja scalająca poszczególne fragmenty życia i myślenia każdego człowieka. Jeśli człowiek nie ma takiej wizji, to miota się i traci energię w poszukiwaniu zarówno oparcia, jak i celu życia i działania. Żyje z dnia na dzień. To już nie on posiada siebie, ale dzień powszedni posiada jego. Od takiego człowieka trudno cokolwiek wymagać ${ }^{21}$

\footnotetext{
19 Tamże, 94-95.

20 Podręcznik Pokolenia JPII.

${ }^{21}$ Znaczy ksiądz, 30.
} 
Streszczenie: Autorka dokonuje rekonstrukcji pedagogii legendarnego duszpasterza młodzieży, dominikanina Jana Góry OP. W tym celu analizuje jego teksty programowe, a także działalność wychowawczą i duszpasterską, odwołując się również do własnych doświadczeń współpracy z Janem Górą. Stara się udowodnić, że Jan Góra OP wypracował spójny program wychowawczo-formacyjny do pracy z młodzieżą, odpowiadający współczesnym potrzebom społecznym i kulturowym. Program ten był przez niego rozwijany i modyfikowany pod wpływem wieloletnich doświadczeń. Potwierdzeniem jego wpływu są ośrodki na Jamnej i na polach lednickich, a także wypowiedzi przedstawicieli kilku pokoleń jego wychowanków.

Słowa kluczowe: duszpasterstwo, duszpasterz, formacja, osobowość integralna, Ruch lednicki

\section{Bibliografia}

$8 x$ JP2, red. Jan W. Góra. Poznań: Lednica 2000 Duszpasterstwo Akademickie Dominikanów, 2009. Góra, Jan OP., W świetle pontyfikatu Jana Pawła II. Radom: Polskie Wydawnictwo Encyklopedyczne, 2014.

Grzegorczyk, Jan. Święty i błazen. Góra w odsłonach Grzegorczyka. Poznań: Wydawnictwo Polskiej Prowincji Dominikanów W drodze, 2017, wyd. II.

Nowak, Marian. Pedagogiczny profil nauk o wychowaniu. Studium z odniesieniami do pedagogiki pielegniarstwa. Lublin: Wydawnictwo KUL, 2012.

Podręcznik Pokolenia JPII. Ojcowskie słowo do młodych świata, Polski i Lednicy, red. Jan W., Góra OP. Poznań: Lednica 2000 Duszpasterstwo Akademickie Dominikanów, 2008.

Tropy lednickie. Dzieło i program Jana Pawła II, red. Jan W., Góra OP. Poznań: Stowarzyszenie Lednica 2000, 2014.

Wiśniewski, Wojciech. Zapisane kartki Ojca Jana Góry. Antologia. Łomianki: Wydawnictwo LTW, 2016.

Zawojska, Teresa. „Wychowanie oparte na wartościach chrześcijańskich jako odpowiedź na poczucie kryzysu sensu we współczesnym świecie”. Paedagogia Christiana 2/40 (2017): 33-51.

...Znaczy ksiądz. Jan W. Góra OP odpowiada na pytania Joanny Kubaszczyk. Radom: Polskie Wydawnictwo Encyklopedyczne, 2014. 